\title{
Developing Rom (Realistic Outdoor Mathematics) Learning Model For Elementary School Students \\ Sunardi ${ }^{1}$, Titik Sugiarti ${ }^{1} \&$ Didik Sugeng Pambudi ${ }^{1}$ \\ ${ }^{1}$ Department of Mathematics Education FKIP Universitas Jember \\ Jl. Kalimantan 37 Jember 68121, East Java, Indonesia
}

\begin{abstract}
:
The process of mathematics learning in Indonesia still face some problems, where some students are still do not like even hate mathematics. This condition causes the passive and the low students' learning achievement. The aim of this research was to describe the result of developing learning model which integrated Realistic Mathematics Education and Outdoor Mathematics, called ROM model using outdoor environment at elementary school. To develop the ROM model, it is employed steps which consists of stages, namely preliminary study, design, realization/construction, tests and revisions. The test result found the ROM model and its instrumentations such as lesson plan, students worksheet, and achievement test was valid, practice and effective to be implemented for supporting teaching mathematics to improve activities and learning achievement of elementary school students.
\end{abstract}

\section{Keywords: Developmental Research, Realistic Mathematics Education, Outdoor Mathematics, ROM Model.}

\section{Introduction}

The condition of process and mathematics learning in Indonesia still face some problems. One of the problem is that many students are still do not like even hate mathematics. This condition causes the passive and the low students' learning achievement.

There are at least two factors that influence a performance of students in mathematics, namely student factor and teacher factor. Students as learners have different individual differences before entering the class, such as interest to learn mathematics, prerequisite knowledge gained from previous levels of education, intellectual ability, and other internal factors of students. On the other hand, teachers also differ in terms of education level, subject matter knowledge, ability to use learning strategies, and so on (Slameto, 2010; Zascerinska, 2013). A class usually has heterogeneous students (mixed class abilities), in which there are students who like or do not like mathematics. Students who have less activities in learning mathematics generally have negative opinions on mathematics, such as scary subjects, deadly, boring, useless, and hated. As a result the learning achievement are low and students will face the problems of mathematics and other subjects at higher education levels (Sam, 1999; Becker \& Schneide, 2006).

In order to improve students' activities and learning mathematics achievement, in Indonesia, since 2000 it has been socialized and implemented a mathematics learning approach in various regions, called Realistic Mathematics Education (RME). RME is a mathematics learning approach derived from the Netherlands. Marpaung (2003), Hadi (2004), Soedjadi (2006), Zulkardi (2006) and Sembiring (2010) stated that the implementation of $\mathrm{RME}$ in Indonesia is purposed to all Indonesian' students that is expected to grow their interest in mathematics and improve their activities and learning achievement.

Besides through RME, Pambudi (1999, 2000) stated that one way to overcome the boredom of students following the process of learning mathematics in Indonesia is that teachers need to occasionally apply methods of teaching mathematics outside of classroom, called Outdoor Mathematics (OM). The researches results of Pambudi (2000), Suyati (2001), Togno (2001), Moss (2007), Jonsson (2009) indicated that the 
use of OM method can improve students' activities and their learning achievement, but unfortunately, OM method are still unfamiliar for Indonesian teachers.

The problem in this research is how to develop a teaching and learning mathematics model using combination of RME and OM, called ROM model to improve activities and learning achievement of elementary school students? Based on this problem, the aim of this research was to describe the development of a teaching and learning mathematics model using RME and OM, called ROM model to improve activities and learning achievement of elementary school students.

\section{Review Literature}

\subsection{Realistic Mathematics Education}

Realistic Mathematics Education (RME) is a mathematics learning approach derived from the Netherlands. Zulkardi (2002) and Hadi (2002) stated that RME views mathematics as a human activity and teaches mathematics to go through the process, and does not seem ready made things. This means teaching mathematics to students rather than feeding students with formulas that must be memorized, but must relate them to real life contextual that is close to students, and relevant to everyday situations.

There are three key principles of RME, namely guided reinvention/ progressive mathematizing, didactical phenomenology, and self-developed models. Moreover, there are five characteristics of RME, namely using context, independent model, student contribution, interactivity, and interrelationships between topics. Teachers begin learning by posing contextual problems close to the world of students. Teachers guide students with activities by training students' reasoning and collaborating to contribute in constructing new knowledge. When guiding students to re-invent the concept, teachers need to give students the opportunity to use their own way to emerge learning trajectory or learning flow and change their own model form called model of. This model is informal mathematics. Furthermore, the teacher directed him to be a formal mathematics, called model for. After finding the formula, they are trained to apply the formula to solve math problems, problems in other subjects, or problems in everyday life. Thus, students have performed the process of horizontal mathematization and vertical mathematization in RME (Armanto, 2002, Sembiring, 2010).

\subsection{Outdoor Mathematics}

Outdoor Mathematics (OM) is a method of teaching mathematics by guiding students to learn mathematics by utilizing the outside environment of the classroom as a place or source of learning. It is a part of outdoor learning and outdoor education, which has long been applied in many countries such as the United States, Europe and Australia (Payne, 1985; Stevens \& Scott, 2002; Dillon, et al., 2006; Kennard, 2007). In Indonesia, the application of learning by utilizing the environment and learning resources outside the classroom is stated in the curriculum of 2013 (Kemdikbud, 2013).

\section{Method}

\subsection{Research Design}

This research was a developmental research (Richey \& Nelson, 1996) which aims to develop a learning model, called ROM model (Realistic Outdoor Mathematics). In order to develop the ROM model it is used the Plomp model which consists of four stages, namely (1) preliminary study; (2) design; (3) realization / construction; (4) tests and revisions (Plomp, 1997). The procedure of this research can be seen at Figure 1.

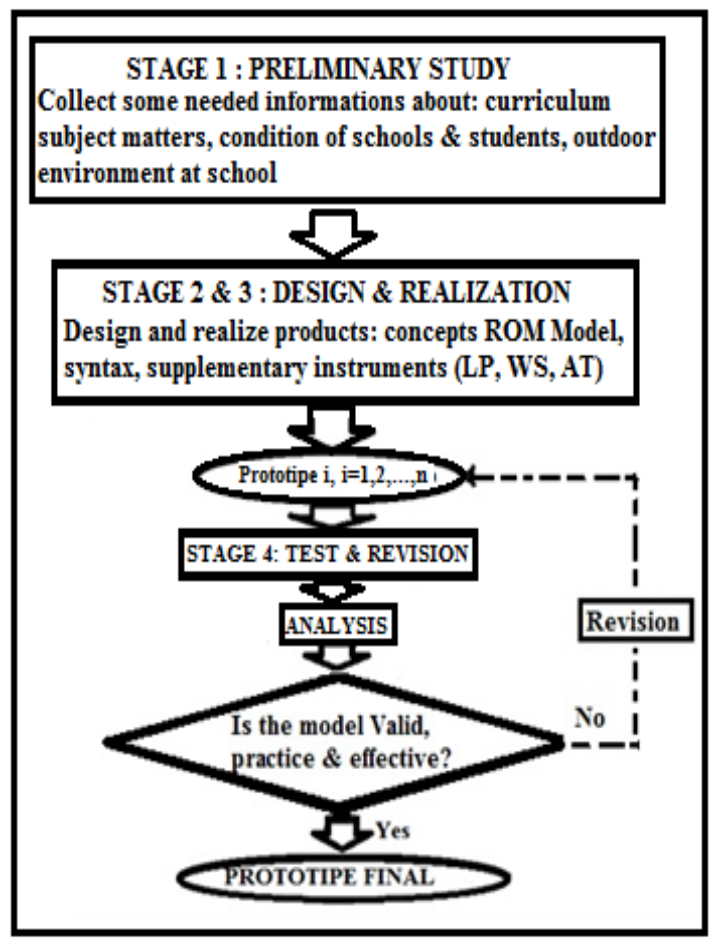

Figure 1. Procedure of the research

\subsection{Collection and Data Analysis}

The data were collected by a means of (a) the feasibility of Instruments Validation, (b) Data 
validity of ROM Model, (c) Data of the practicability of ROM Model, and (d) Data on the effectiveness of ROM Model. For data (a) it was obtained from the assessment of 3 validators, while data (b), (c), and (d) were obtained from the assessment of 3 validators, and also obtained from the assessment results during the ROM model tests (implementation) in the school. The effectiveness data of the ROM model consists of (a) students activities, (b) results of Achievement Test, (c) teacher's ability to manage learning process, and (d) students and teacher response to ROM model implementation in the school.

The validator provides an assessment by giving a checklist mark $(\sqrt{ })$ in the answer choices consisting of $1=$ very less, $2=$ less, $3=$ enough, 4 $=$ good and $5=$ very good. ROM model is declared valid if the Va value is $\geq 4.0$ or not valid if the Va value is $<4.0$. The practicality of the ROM model is assessed by the criteria: ROM model is practical if $\mathrm{Va} \geq 4.0$ or is not practical if $\mathrm{Va}<4.0$. The effectiveness of the ROM model was assessed by the criteria as follows: (a) students' activities, if the number of active students are $\geq 75 \%$, (b) Results of the student's Achievement Test $\geq 70$ ), (c) teacher's ability to manage learning process with score $\mathrm{Va} \geq 4.0$, and (d) students' responses that support the application of the ROM model $\geq 75 \%$, and teacher give a positive response to ROM model implementation in the school.

\section{Results and Discussions \\ 4.1 Design of ROM Model}

The ROM model is defined as a learning model that integrates $\mathrm{RME}$ and $\mathrm{OM}$ to guide students to learn mathematical concepts and apply them in solving contextual problems related to out of classroom environment and aims to enhance learning outcome of students in mathematics. The characteristics of the developed ROM model are (1) the existence of contextual problems related to outside environment at the beginning of learning, (2) the existence of study groups to collaborate and interact in the discovery concept and application of concepts, (3) the existence of real objects (media) out of classroom, and (4) learning is done in the classroom and the natural environment outside the classroom. Providing contextual problems at the beginning of learning is a way of motivating and challenging students to learn. The issues raised are issues that are contextual or related to the outside environment around the school.

\subsection{Design of the Syntax ROM Model}

ROM model syntax is obtained by integrating RME syntax with OM syntax. The steps of applying RME are as follows: (1) giving contextual problem, (2) grouping students, (3) guiding students to find the concept (re-invention) and applying found concepts in solving problems, (4) guiding students to making reports and presenting the results to the group work, (5) guiding students to conclude lessons, (6) assessing both student activity and student learning outcomes. The steps of applying the OM method are as follows: (1) grouping students, (2) guiding students to find concepts and applying them by using the natural environment outside of classroom; (3) guiding students to create reports and present group work results; (4) guiding students to conclude the lesson, (5) assessing both student activities and student learning outcomes.

From the RME and OM syntax, then it is integrated with the learning phase, starting from (1) Introduction, (2) Organization, Implementation, (4) Report, (5) Closing, and (6) Assessment. Activities were undertaken by teachers and students in implementing the learning process, where, at the introduction phase, the teacher is obligated to assign contextual problems, giving apperception, and conveying learning objectives. In the organizing phase, teacher guides students to make study groups, and share learning media. Next, in the implementation phase, the teacher guides the students to do the activity of finding concepts and applying the concept. The place of learning is chosen for the natural environment outside of classroom, such as the schoolyard. In the reporting phase, teachers guide students to make reports and present it in the classroom. Furthermore, the teacher guides the students to conclude the lesson. In the assessment phase, the teacher assesses both student' activities and student' learning achievement. The details of each phase along with teacher and student activities on the ROM model syntax offered can be seen in Table 1. 
Table 1.The Syntax of ROM Model

\begin{tabular}{|c|c|c|}
\hline $\begin{array}{l}\text { PHASE OF } \\
\text { LEARNING }\end{array}$ & TEACHER ACTIVITIES & STUDENT ACTIVITIES \\
\hline $\begin{array}{l}\text { INTRODUCTION } \\
\text { (Giving Contextual } \\
\text { Problems by using } \\
\text { context out of } \\
\text { classroom } \\
\text { environment) }\end{array}$ & $\begin{array}{l}\text { 1. Preparing students to learn } \\
\text { 2. Giving Apperception } \\
\text { 3. Stating the goal of learning } \\
\text { 4. Providing contextual } \\
\text { problems (in the Students } \\
\text { Worksheet (SW) }\end{array}$ & $\begin{array}{l}\text { 1. Preparing learning } \\
\text { equipment } \\
\text { 2. Recalling past lesson } \\
\text { material } \\
\text { 3. Understanding goal of } \\
\text { learning } \\
\text { 4. Observing, and } \\
\text { understanding the contextual } \\
\text { problems in SW }\end{array}$ \\
\hline $\begin{array}{l}\text { ORGANIZATION } \\
\text { (Community Learning } \\
\text { \& Interactivities) }\end{array}$ & $\begin{array}{l}\text { 1. Guiding students to make } \\
\text { study groups } \\
\text { 2. Distributing SW to each } \\
\text { group, as well as media/ tools } \\
\text { that students need to learn } \\
\text { 3. Giving explanations to } \\
\text { students }\end{array}$ & $\begin{array}{l}\text { 1. Making study groups } \\
\text { 2. Receiving SW and media } \\
\text { from Teacher } \\
\text { 3. Observing and inquiring } \\
\text { about the function of the } \\
\text { media }\end{array}$ \\
\hline $\begin{array}{c}\text { ACTION } \\
\text { (Community learning, } \\
\text { Guided Reinvention, } \\
\text { Interactivities, } \\
\text { Students' } \\
\text { Contributions) }\end{array}$ & $\begin{array}{l}\text { 1. Taking students to go outside } \\
\text { of classroom in order to } \\
\text { discover the concepts and } \\
\text { apply the concepts to the } \\
\text { natural environment } \\
\text { 2. Guiding students to } \\
\text { understand the contextual } \\
\text { problems that exist in the SW. } \\
\text { 3.Conditioning students in } \\
\text { groups to actively discuss and } \\
\text { cooperate among members of } \\
\text { the group. } \\
\text { 4.Guiding students to do } \\
\text { activities of doing } \\
\text { mathematics to solve } \\
\text { contextual problems. }\end{array}$ & $\begin{array}{l}\text { 1.Learning to find concepts } \\
\text { and apply concepts to the } \\
\text { environment outside of the } \\
\text { classroom according to the } \\
\text { teacher's direction } \\
\text { 2. Understanding the } \\
\text { contextual problems that } \\
\text { exist in the SW } \\
\text { 3.Actively discuss and } \\
\text { cooperate among members } \\
\text { of the group. } \\
\text { 4.Conducting activities (doing } \\
\text { mathematics) in order to } \\
\text { solve contextual problems. }\end{array}$ \\
\hline $\begin{array}{c}\text { REPORTING } \\
\text { (Community learning, } \\
\text { Self-developed } \\
\text { Models, model of, } \\
\text { model for, } \\
\text { Interactivities, } \\
\text { Students' } \\
\text { Contribution) }\end{array}$ & $\begin{array}{l}\text { 1. Guiding students to complete } \\
\text { SW and make a reporting } \\
\text { 2. Asking the group } \\
\text { representative to report / } \\
\text { present the group work. } \\
\text { 3. Discussing the results of } \\
\text { group work. } \\
\text { 4. Guiding students to } \\
\text { understand the formal } \\
\text { mathematical form of } \\
\text { contextual problem solving. }\end{array}$ & $\begin{array}{l}\text { 1. Completing the SW and } \\
\text { making a reporting } \\
\text { 2. Reporting / presenting the } \\
\text { work of the group } \\
\text { (representative). } \\
\text { 3. Following the discussion of } \\
\text { group work results. } \\
\text { 4. Understanding the teacher's } \\
\text { explanation of the formal } \\
\text { mathematical form of } \\
\text { contextual problem solving. }\end{array}$ \\
\hline $\begin{array}{c}\text { ENCLOSING } \\
\text { (Reflection \& } \\
\text { Students' Contribution }\end{array}$ & $\begin{array}{l}\text { 1. Guiding students to conclude } \\
\text { the lesson. } \\
\text { 2. Giving Tests and homework }\end{array}$ & $\begin{array}{l}\text { 1. The student concludes the } \\
\text { lesson. } \\
\text { 2. Students notes homework. }\end{array}$ \\
\hline
\end{tabular}




\begin{tabular}{|c|l|l|}
\hline $\begin{array}{c}\text { ASSESSMENT } \\
\text { (Authentic }\end{array}$ & $\begin{array}{l}\text { 1. Observing and assessing } \\
\text { student activities during the }\end{array}$ & $\begin{array}{l}\text { 1. Conducting activities } \\
\text { during the learning process. }\end{array}$ \\
Assessment) & $\begin{array}{l}\text { learning process. } \\
\text { 2. Providing assessment of } \\
\text { learning outcome (cognitive } \\
\text { test). }\end{array}$ & $\begin{array}{l}\text { outcome (cognitive test) } \\
\text { well. }\end{array}$ \\
& & \\
\hline
\end{tabular}

The syntax is a general pattern that can be applied according to the material and time of the lesson. For example if at a material meeting is not completed, and the time is insufficient, then the teacher can continue the unfinished activity at the next meeting time.

\subsection{The example of contextual problems}

The following are the examples of contextual mathematics problems which are employing the school's flagpole context to learn the triangle concept for elementary students. "Every Monday and National freeday, school community always do flag ceremony. Do you know how to measure the height of the flagpole?" To answer the question, you can do an experiment with your work group to measure the height of the flagpole in the schoolyard by using the triangle concepts.

The following are the examples of contextual mathematics problems in the achievement test (AT):

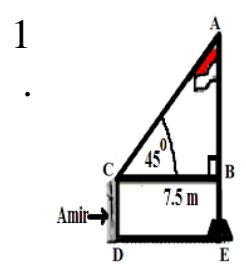

One day, Amir see the top of flag pole with the elevation angle of $45^{\circ}$. The distance of the flagpole with Amir's standing position is $7.5 \mathrm{~m}$ and the flag pole's height is $9 \mathrm{~m}$. What is Amir's height?

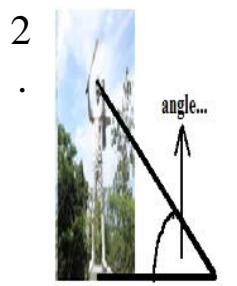

A fourth grader student want to measure the Pattimura's monument in Ambon, Maluku Province. He uses the angle elevation as the comparison (see the picture). What is the exact angle? Give your reason!

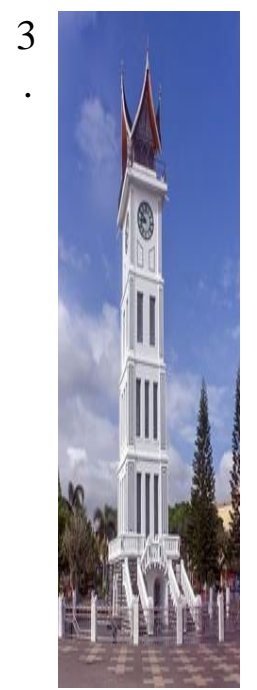

In the Bukit Tinggi región, West Sumatra, there is a tower called Jam Gadang, meaning A giant watch. The tower was built by the Dutch collony by the year of 1926. In the bright daylight, a student which $100 \mathrm{~cm}$ tall is standing in front of that tower watching the edge of the tower from the distance of $25 \mathrm{~m}$. When the edge of the tower is directed to the student's head and to the tower's pole, it is formed a right triangle. Please make a sketch and calculate the height of the tower!

\section{Figure 2. Mathematical Contextual Problems}

\subsection{The Result of the Stage Test and Revision}

All products have been developed in this research. They are consisting of ROM draft model and the learning instruments which has been validated by 3 experts. The ROM model validity is seen from two aspects namely (1) the content validity and (2) construct validity. There are 9 aspects to be considered for the ROM model content validation. From the 3 validator, it is obtained the average value as in the following: aspect (1) the supporting theory of ROM which is 4.3, (2) ROM syntax model which is 4.3, (3) social system which is 4.4 , (4) managing reaction principal which is 4.2 , (5) supporting system which is 4.3 , (6) instructional impact and its accompanist which is 4.2 , (7) learning implementation which is 4.4 , (8) learning environment and managing task which is 4.3 and (9) grading/ evaluating which is 4.3. The total average score $(\mathrm{Va})$ from the content validation model of ROM is 4.3. This shows that the ROM model is Valid for the content aspect. 
There are 10 aspects to be considered for ROM validation construct model. From 3 validators, it is obtained the average value as in the following: aspect (1) the model component of ROM which is 4.2 , (2) the supporting theory which is 4.2 , (3) syntax which is 4.2 , (4) social system which is 4.3 , (5) managing reaction principal which is 4.3 , (6) supporting system which is 4.1 , (7) instructional impact and its accompanist which is 4.2, (8) learning implementation which is 4.1 , (9) learning environment and managing task which is 4.2 and (10) grading/ evaluating which is 4.2. the average total score (Va) is 4.2 which indicates that ROM model is Valid for the constructional aspect.

\subsection{The Validation Result of Learning Instructio-nal}

The learning instructional which are validated were Lesson Plan (LP), Student Worksheet (SW), and Achievement Test (AT). There are 6 aspects to be considered to validate LP. From the 3 validators, it is obtained the average aspect score as in the following: aspect (1) working criterion which is 4.1 , (2) the presented content which is 4.3 , (3) the language which is 4.1 , (4) the time which is 4.2 , (5) presentation method which is 4.2 and (6) closing which is 4.2 . The total average score of LP validation ( $\mathrm{Va}$ ) is 4.2. This shows that LP is Valid and feasible to be implemented at the school.

There are 3 aspects to be considered to validate SW. From the 3 validators, it is obtained the average aspect score as in the following: aspect (1) organization which is 4.6 , (2) procedures which is 4.5 , (3) questioning/problem which is 4.4 . The average validation score ( $\mathrm{Va}$ ) for $\mathrm{SW}$ is 4.5 . This shows that the SW is Valid and feasible to be implemented at the school.

There are 3 aspect to be considered to validate AT. From the 3 validators, it is obtained the average aspect score as in the following: aspect (1) material which is 4.3 , (2) construction which is 4.1 and (3) language which is 4.2. The average validation score (Va) 4.2. This shows that the AT is Valid and feasible to be implemented at the school.

\subsection{The Validation Result of the ROM model Practicality \\ The implementation and practicality grading} of ROM model was gained from 3 validators pervading the aspects of (1) syntax which is 4.2 ,
(2) social system which is 4.4 and (3) managing principal action which is 4.3 . The average score (Va) is 4.3. This shows that the validators believe that ROM model is practical or feasible to be implemented at the school.

\subsection{The Practicality Analysis and ROM Model Effectiveness in the School}

To test the practicality and the ROM model effectiveness, there was a trial implementation of ROM in the school. The school was in an elementary school, namely SD Negeri Karangrejo 02 Jember located in Sriwijaya Street No. 19 Sumbersari, Jember. The subjects were fourth grade students consisting of 31 students. The students were divided into 6 groups. Each group consists of 5 students, and one group consisting 6 students. The ROM Model implementation were done 3 times of meeting on $5^{\text {th }}$ to $9^{\text {th }}$ April 2018.

In the first meeting, the teacher implemented the introduction phase, which aims to get student ready to learn, to give information of learning task, to make 6 groups, to give the SW and media like protactor, roll meter, and right triangle to every group. The teacher conducted apperception to remind students about the triangle concepts. After that, the students were directed to go outside of classroom. In the school yard, the studens were given opportunities to practice in their group to find the way to measure the flagpole by employing the right triangle concepts. After that, the students were asked to measure the flag pole by using the flag's borer rope and the given media. Every group was succesful to find how to measure the height of a flag pole. The way is one student with the initial A was pulling the borer rope to few meters with the elevation angle of $45^{\circ}$, and the other student with the initial $\mathrm{B}$ was drawing the right triangle. The other student, with the initial C, measured the distance between the students and the flagpole (i.e $\mathrm{x}$ meters) and the student's tall (i.e $\mathrm{y}$ meters). Based on the right triangle characteristic, it is obtained that the flagpole's height is $(\mathrm{x}+\mathrm{y})$ meters.

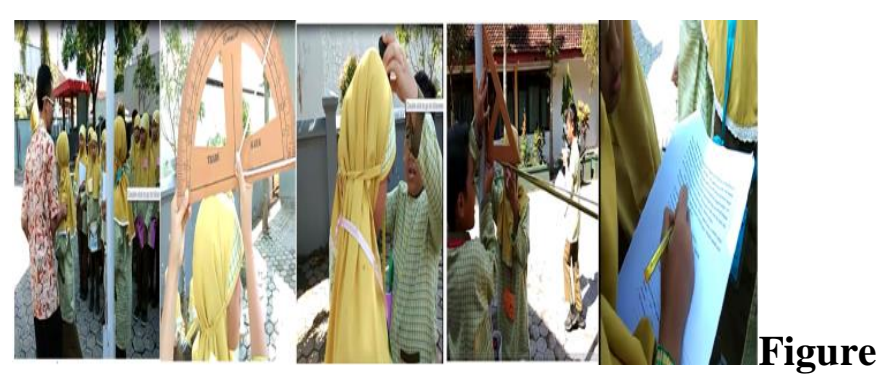

3. Students' Learning using flagpole in the Schoolyard 
In the second meeting, the students were guided by teacher to fill the SW and made presentation report. The teacher asked students to discuss, quest and answer and present their work result in return. In the presentation event, the teacher guided students to make a form of mathematical formal from students discovery that they got from the outside practice. All groups can make their working report as in the following

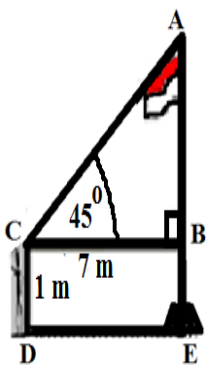

The form of BCED is a rectangle, so $\mathrm{BC}=\mathrm{DE}=7 \mathrm{~m}$ and $\mathrm{CD}=\mathrm{BE}=1 \mathrm{~m}$. Because the angle of $\mathrm{ACB}$ is $45^{\circ}$, so $\mathrm{AB}=\mathrm{BC}$. Because $\mathrm{BC}=7$ $\mathrm{m}$, then $\mathrm{AB}=7 \mathrm{~m}$. Because $\mathrm{CD}=\mathrm{BE}=1 \mathrm{~m}$, then $\mathrm{AE}=$ $A B+B E=7 m+1 m=8 m$. Thus, the height of the flagpole is 8 meters.

Figure 4. Using concept of the Right Triangle Students Measure the Height of a Flagpole

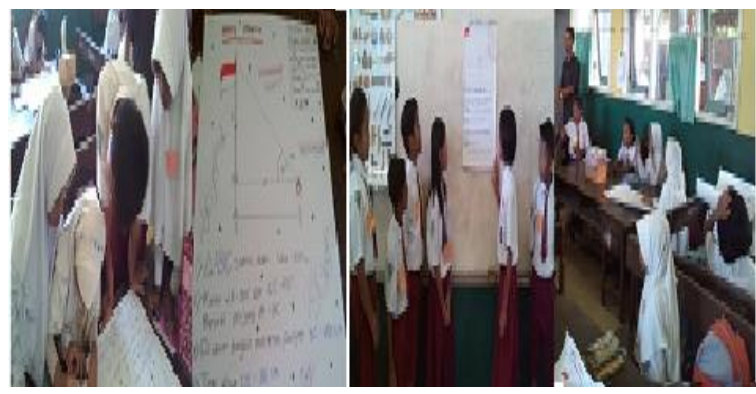

Figure 5. Situation of Students' Presentation

In the third meeting, the students were asked to do the post test. After their works were collected, the student were given research questionairre to see how is their response toward the ROM model implementation. The data of activeness, students learning achievement, and response can be seen in Table 2.

Table 2. Data of Activities, Learning Achievement and Response of Students

\begin{tabular}{|c|c|c|c|c|}
\hline \multirow{2}{*}{$\begin{array}{l}\mathbf{N} \\
\text { o. }\end{array}$} & \multirow{2}{*}{$\begin{array}{l}\text { Name of } \\
\text { Students }\end{array}$} & \multicolumn{3}{|c|}{ Score } \\
\hline & & $\begin{array}{c}\text { Activiti } \\
\text { es } \\
\text { (Active } \\
\text { / } \\
\text { Passive }\end{array}$ & $\begin{array}{c}\text { Learn } \\
\text { ing } \\
\text { Achie } \\
\text { ve- } \\
\text { ment }\end{array}$ & $\begin{array}{c}\text { Res- } \\
\text { pons } \\
\text { e } \\
(+/-)\end{array}$ \\
\hline
\end{tabular}

\begin{tabular}{|c|c|c|c|c|}
\hline & & ) & & \\
\hline 1. & $\begin{array}{l}\text { Ahmad } \\
\text { Z }\end{array}$ & A & 73.33 & + \\
\hline 2. & Aditya A & $\mathrm{A}$ & 86.67 & + \\
\hline 3. & Alfian D & $\mathrm{A}$ & 73.33 & + \\
\hline 4. & $\begin{array}{l}\text { Ananda } \\
\mathrm{S}\end{array}$ & $\mathrm{A}$ & 80.00 & + \\
\hline 5. & Assyfa R & $\mathrm{A}$ & 76.67 & + \\
\hline 6. & $\begin{array}{l}\text { Amelya } \\
\text { E }\end{array}$ & $\mathrm{A}$ & 80.00 & + \\
\hline 7. & $\begin{array}{l}\text { Danakitr } \\
\text { i A }\end{array}$ & $\mathrm{A}$ & 80.00 & + \\
\hline 8. & $\begin{array}{l}\text { Danish } \\
\text { A } \\
\end{array}$ & $\mathrm{A}$ & 70.00 & + \\
\hline 9. & Dewi M & $\mathrm{A}$ & 73.33 & + \\
\hline $\begin{array}{l}10 \\
.\end{array}$ & Dewi S & $\mathrm{A}$ & 80.00 & + \\
\hline 11 & Diah P & $\mathrm{A}$ & 80.00 & + \\
\hline 12 & $\begin{array}{l}\text { Imsania } \\
\text { A }\end{array}$ & A & 73.33 & + \\
\hline $\begin{array}{l}13 \\
.\end{array}$ & Jesica R & A & 76.67 & + \\
\hline 14 & Jovita N & $\mathrm{A}$ & 80.00 & + \\
\hline 15 & Merly C & $\mathrm{A}$ & 76.67 & + \\
\hline 16 & $\begin{array}{l}\text { Meyida } \\
\text { A }\end{array}$ & $\mathrm{A}$ & 73.33 & + \\
\hline $\begin{array}{l}17 \\
.\end{array}$ & M. Afif & $\mathrm{A}$ & 80.00 & + \\
\hline 18 & M. Rofii & $\mathrm{A}$ & 70.00 & + \\
\hline 19 & Muh. D & $\mathrm{A}$ & 80.00 & + \\
\hline $\begin{array}{l}20 \\
.\end{array}$ & $\begin{array}{l}\text { Nurdina } \\
\mathrm{K}\end{array}$ & $\mathrm{A}$ & 83.33 & + \\
\hline $\begin{array}{l}21 \\
.\end{array}$ & $\begin{array}{l}\text { Nabila } \\
\text { W }\end{array}$ & $\mathrm{A}$ & 100.00 & + \\
\hline 22 & Nadira D & $\mathrm{A}$ & 73.33 & + \\
\hline 23 & $\begin{array}{l}\text { Nafisya } \\
\text { A }\end{array}$ & $\mathrm{A}$ & 70.00 & + \\
\hline 24 & $\begin{array}{l}\text { Nezhava } \\
\text { E }\end{array}$ & $\mathrm{A}$ & 70.00 & + \\
\hline
\end{tabular}




\begin{tabular}{|c|c|c|c|c|}
\hline 25 & Naufal R & $\mathrm{A}$ & 73.33 & + \\
\hline 26 & Nazril & $\mathrm{A}$ & 83.33 & + \\
\hline 27 & Naila $S$ & A & 76.67 & + \\
\hline 28 & Nurul R & $\mathrm{A}$ & 93.33 & + \\
\hline 29 & $\begin{array}{l}\text { Paulina } \\
\text { D }\end{array}$ & $\mathrm{A}$ & 83.33 & + \\
\hline 30 & $\begin{array}{l}\text { Rahma } \\
\mathrm{N}\end{array}$ & $\mathrm{A}$ & 83.33 & + \\
\hline 31 & $\begin{array}{l}\text { Zaskya } \\
\text { Z }\end{array}$ & A & 76.67 & + \\
\hline & Average & $\begin{array}{l}100 \% \\
\text { Active }\end{array}$ & 78.39 & $\begin{array}{c}100 \\
\% \\
(+)\end{array}$ \\
\hline
\end{tabular}

The observation result toward teacher's ability to apply the ROM Model in SDN Karangrejo 2 Jember can be seen at Table 3.

\section{Tabel 3. The Teacher's Ability in Managing of Learning Process}

\begin{tabular}{|c|l|c|}
\hline No. & \multicolumn{1}{|c|}{ Observed aspects } & Score (Va) \\
\hline I. & Introduction & 4,50 \\
\hline II. & Organization & 4,50 \\
\hline III. & Action & 4,30 \\
\hline IV. & Reporting & 4,50 \\
\hline V. & Closing & 4,40 \\
\hline VI. & Grading & 4,20 \\
\hline VII. & Time allocation & 4,20 \\
\hline VIII. & Environment observation & 4,30 \\
\hline & Average Total Score (Va) & $\mathbf{4 . 3 5}$ \\
\hline
\end{tabular}

From the average total score (Va) of the observation result toward teachers ${ }^{6}$ ability in managing the learning process by applying ROM model is 4.35 of the 5 maximum score. The score is catagorized as Good (High category).

\section{Discussion}

From the data result analysis, it is shown that the ROM model is practical to be implemented at elementary school.

From the result analysis effectiveness of ROM model, it can be seen as follow. First, from the students' activities, all of them (100\%) did their learning activity with various style and support the ROM model implementation. Those activities include oral, reading, writing, motoric and thinking for solving problems (mental activities). The activities were various pervading (1) listening to their teacher, (2) asking, (3) reading the modul and book, (4) answering the question, (5) discussing with their peer, (6) holding the borer rope, (7) measuring the distance, (8) writing notes, (9) drawing vignatte, (10) walking to the flag pole, (11) thinking, (12) filling the students' worksheet, (13) making reports, (14) presenting, and (15) answering the post test.

Second, from the learning achievement test (AT), it is shown that $100 \%$ students got the average score of 78.39. Those category is good and $75 \%$ of students got the minimum score of 70 . Third, from the observation result recapitulation toward the teachers' ability to manage learning process by applying ROM model, it is gained that the $\mathrm{Va}$ is 4.35 . This shows that the teacher is able to implement the syntax model of ROM with the good (high category). Fourth, all students $(100 \%)$ and teacher gave their positive responses or in this case all of them give positive support to the implementation of ROM model in the elementary school.

From the data analysis report which pervading the validation, data practicality, and ROM model effectiveness, it is concluded that Realistics Outdoor Mathematics (ROM) model that has been developed throught this research meets the valid criteria, practical and effective to be implemented in the elementary school. From the students' activeness data analysis and their test results, ROM is also able to be an alternative teaching way to improve students' activities and students' ${ }^{6}$ achievement of mathematics learning.

\section{Conclusion}

This research has been developed the learning model called ROM model that the model was valid, practice and effective to be implemented at elementary school. A product was a ROM model supplemented with instructional instrumentations, such as lesson plan, students worksheet, and achievement test can be used for supporting teaching mathematics to improve activities and learning achievement of elementary school students. The teachers in elementary school need to implement the ROM model by following the syntax that has been arranged and they need to consider 
the schoolyard condition that provides the sufficient learning media.

\section{Acknowledgments}

The authors would like to thank DRPM Kemenristekdikti and Universitas Jember for supporting the Research Grant Stranas Institusi, contract number: 058/SP2H/LT/DRPM/2018 and 1373/UN25.3.1/LT/2018, dated 26 March 2018. Likewise, the author's gratitude goes to SDN Karangrejo 02 Jember that has provided collaborative research opportunities.

\section{References}

[1] Armanto, D. (2002). Teaching Multiplication and Division Realistically in Indonesian Primary Schools: A Prototype of Local Instructional Theory. Doctoral dissertation. Universty of Twente, Enschede, The Netherlands. (http:// core.ac.uk/ download/pdf/ 11462403.pdf), [21 Januari 2008].

[2] Bhandari, R. (2012). The Potential of Outdoor Focus on Mathematical Concepts and Role of Pedagogue. Thesis : Oslo and Akershus University, DIT and University of Malta.

[3] Ball, D. L. \& Bass, H. (2000). Making believe: The collective Construction of Public Mathematical Knowledge in the Elementary Classroom. In Phillips, D. C. Constructivism in Education. The University of Chicago Press: Chicago, IL. (http://www-personal.umich.edu/ dball/ chapters/ Ball Bass Making Believe.pdf ), [5 Maret 2008].

[4] Dillon, J., et. al. (2006). The Value of Outdoor Learning: Evidence from Research in the UK and Elsewhere. School Science Review, (3) 2006, 87(320) :107-111.

[5] Hadi, S. (2002). Effective teacher professional development for implementation of Realistic Mathematics Education in Indonesia. Doctoral dissertation, University of Twente, Enschede, The
Netherlands.(http://core.ac.uk/ download/ pdf/ 11462401.pdf), [21 Januari 2008].

[6] Jonsson, D. (2009). Learning Mathematics Out of Doors. Paper submitted to Karlstads Universitet Faculty of Mathematics, 25 Mei 2009, [10 Januari 2010].

[7] Kemdikbud.(2013). Kurikulum 2013 [Curriculum 2013]. Jakarta: Kemdikbud.

[8] Kennard, J. (2007). Outdoor Mathematics. Mathematics Teaching, March 2007, issue 201, p: $16-18$

[9] Moss, M. (2007). Outdoor Mathematical Experiences: Constructivism, Connections, and Health. (http://math.unipa.it/ grim/21 project/21_ charlotte Moss Workshop Edit.pdf), [2 April 2008].

[10] Pambudi, D. S. (1999). Outdoor Mathematics : An Alternative to Motivate Students to Learn Mathematics in Indonesia. Paper presented on The $8^{\text {th }}$ South East Asian Conference on Mathematics Education (SEACME) at Ateneo De Manila University Philippines, 30 May - 4 June 1999, p.69.

[11] Pambudi, D. S. (2000). Effects of Outdoor Mathematics on the Motivation and Learning Achievement of Students. UNITAS Journal, Los Banos, Philippines, III, 22-32.

[12] Payne, Milton R. (1985). Using the Outdoors to Enrich the Learning of Mathematics. ERIC, New Mexico State University, USA.

[13] Plomp, T. 1997. Educational and Training System Design. Enschede, The Netherlands: University of Twente.

[14] Richey, R. \& Nelson. (1996). "Developmental Research". In Jonassen (Ed) Handbook of Research for Educational Communications and Technology. New York: Macmillan Simon \& Schuster.

[15] Sam, L.C. (1999). Public Images of Mathematics. (http://www.people.ex. ac.uk/ PErnest/pome15/ lim chap sam.pdf), [25 Maret 2008]. 
[16] Sembiring, R. K. (2010). Realistic Mathematics Education in Indonesia. JME. I (1), 11-16.

[17] Stevens, J \& Scott, K. (2002). Developing Mathematics Out-of-Doors. Mathematics Teaching, Issue 180, September 2002:2022.

[18] Togño, E. C. (2001). "Outdoor Mathematics: Its Effects In Teaching Trigonometry" (http://www. naga.gov.ph/ library/theses/unc/togno.html), [5 Maret 2002].
[19] Zaščerinska, J., Zaščerinskis, M., Andreeva, N., \& Aleksejeva, L. (2013). Factors that Influence the Educational Process. International Journal of Modern Education, II (3): 57-65.

[20] Zulkardi (2002). Developing a Learning Environtment on RME for Indonesia Student Teachers. (http:// eprints.unsri.ac.id/615/1/ thesis Zulkardi. pdf [21 Januari 2008]. 